\title{
Pulmonary Hypertension and Exercise Training: Evidence Based Studies
}

\section{Leonardo Roever $^{1^{*}}$ and Anaisa Silva Roerver Borges ${ }^{2}$}

${ }^{1}$ Federal University of Uberlândia, Department of Clinical Research, Brazil

${ }^{2}$ Master Institute of Education President Antonio Carlos - IMEPAC-Araguari, Brazil

\section{Introduction}

Pulmonary Hypertension (PH) is regarded as a mean pulmonary artery pressure greater than $25 \mathrm{~mm} \mathrm{Hg}$ in the setting of normal or reduced cardiac output and a normal pulmonary capillary wedge pressure. A constellation of permissive and provocative factors exists, various mechanisms are activated that lead to vascular constriction, cellular proliferation, and a prothrombotic state in varying degrees, which results in $\mathrm{PH}$ and its clinical sequelae [1-6].

Three mechanistic pathways are known in patients with $\mathrm{PH}$. (A) The endothelin (ETn): Big-ETn is converted in endothelial cells to ETn-1 by endothelin-converting enzyme (ECE). ET-1 binds to PASMC ETnA and ETnB receptors, which ultimately leads to PASMC contraction, proliferation, and hypertrophy. ETn-1 binds to endothelial cell Also ETB receptors. (B) The prostacyclin (PGI2): The production of PGI2 is catalyzed by prostacyclin synthase in endothelial cells. In PBMCs, PGI2 stimulates adenylate cyclase, thus increasing production of cAMP from ATP, another second messenger que maintains PASMC relaxation and inhibition of proliferation PASMC. (C) The NO: NO is created in endothelial cells by type III NO synthase, which in turn induces guanylate cyclase (GC) to convert guanosine triphosphate (GTP) to cGMP, the second messenger que constitutively maintains pulmonary artery smooth muscle cell (PASMC) relaxation and inhibition of proliferation PASMC [7]. PH is classified according to Table 1.

\begin{tabular}{|c|c|}
\hline $\begin{array}{l}\text { 1. Pulmonary arterial hypertension } \\
\text { (PH) }\end{array}$ & $\begin{array}{l}\text { 2. Pulmonary hypertension with left heart } \\
\text { disease }\end{array}$ \\
\hline 1.1. Idiopathic (IPH) & $\begin{array}{l}\text { 2.1. Left-sided atrial or } \\
\text { ventricular heart disease }\end{array}$ \\
\hline 1.2. Familial (FPH) & disease 2.2. Left-sided valvular heart \\
\hline 1.3. Associated with (APH): & $\begin{array}{l}\text { 3. Pulmonary hypertension associated } \\
\text { with lung diseases and/or hypoxemia }\end{array}$ \\
\hline 1.3.1. Collagen vascular disease & $\begin{array}{l}\text { 3.1. Chronic obstructive } \\
\text { pulmonary disease }\end{array}$ \\
\hline $\begin{array}{l}\text { 1.3.2. Congenital systemic-to- } \\
\text { pulmonary shunts }\end{array}$ & 3.2. Interstitial lung disease \\
\hline 1.3.3. Portal hypertension & 3.3. Sleep-disordered breathing \\
\hline 1.3.4. HIV infection & $\begin{array}{l}\text { 3.4. Alveolar hypoventilation } \\
\text { disorders }\end{array}$ \\
\hline 1.3.5. Drugs and toxins & altitude 3.5 . Chronic exposure to high \\
\hline $\begin{array}{l}\text { 1.3.6. Other (thyroid disorders, } \\
\text { glycogen storage disease, }\end{array}$ & $\begin{array}{l}\text { 3.6. Developmental } \\
\text { abnormalities }\end{array}$ \\
\hline $\begin{array}{l}\text { Gaucher's disease, hereditary } \\
\text { hemorrhagic telangiectasia, } \\
\text { hemoglobinopathies, } \\
\text { myeloproliferative disorders, } \\
\text { splenectomy) }\end{array}$ & $\begin{array}{l}\text { 4. Pulmonary hypertension due to chronic } \\
\text { thrombotic }\end{array}$ \\
\hline $\begin{array}{l}\text { 1.4. Associated with significant } \\
\text { venous or capillary involvement }\end{array}$ & and/or embolic disease (CTEPH) \\
\hline $\begin{array}{l}\text { 1.4.1. Pulmonary veno-occlusive } \\
\text { disease (PVOD) }\end{array}$ & $\begin{array}{l}\text { 4.1. Thromboembolic obstruction } \\
\text { of proximal pulmonary arteries }\end{array}$ \\
\hline $\begin{array}{l}\text { 1.4.2. Pulmonary capillary } \\
\text { hemangiomatosis }(\mathrm{PCH})\end{array}$ & $\begin{array}{l}\text { 4.2. Thromboembolic obstruction } \\
\text { of distal pulmonary arteries }\end{array}$ \\
\hline \multirow[t]{3}{*}{$\begin{array}{l}\text { 1.5. Persistent pulmonary } \\
\text { hypertension of the newborn }\end{array}$} & $\begin{array}{l}\text { 4.3. Nonthrombotic pulmonary } \\
\text { embolism }\end{array}$ \\
\hline & material) \\
\hline & 5. Miscellaneous \\
\hline
\end{tabular}

Table 1: WHO Classifications of Pulmonary Hypertension
Pandey and colleagues reported a prospective intervention studies that evaluated the efficacy and safety of exercise training (ET) in patients with PH. Primary outcome of this meta-analysis was a change in six-minute walk distance (6MWD). The authors also assessed the effect of exercise on peak oxygen uptake $\left(\mathrm{VO}_{2}\right.$ peak), resting pulmonary arterial systolic pressure (PASP), peak exercise heart rate (HR peak), and quality of life. A total of 16 studies with 434 exercisetraining participants were included. ET was associated with significant improvement in 6MWD [Weighted mean difference (WMD): 57.7 meters ( $95 \%$ CI: 42.5 to 72.8$)$ ], $\mathrm{VO}_{2}$ peak [WMD $=1.7 \mathrm{ml} / \mathrm{kg} / \mathrm{min}(95 \%$ CI: 1.3 to 2.0$)$ ], PASP [WMD $=-3.6 \mathrm{mmHg}(95 \% \mathrm{CI}=-5.8$ to -1.4$)$ ], $\mathrm{HR}$ peak [WMD $=10.4$ beats per $\min (95 \%$ CI: 5.5 to 15.3$)$ ], and quality of life as measured on SF-36 questionnaire subscale scores. ET was well tolerated with a low dropout rate and no major adverse events [8].

ET in patients with $\mathrm{PH}$ is associated with a significant improvement in exercise capacity, pulmonary arterial pressure and quality of life.

\section{References}

1. Kiely DG, Elliot CA, Sabroe I, Condliffe R (2013) Pulmonary hypertension: diagnosis and management. BMJ 346: f2028.

2. Simonneau G, Robbins IM, Beghetti M, Channick RN, Delcroix M, et al. (2009) Updated clinical classification of pulmonary hypertension. J Am Coll Cardiol 54: S43-54.

3. Perez VA, Haddad F, Zamanian RT (2012) Diagnosis and management of pulmonary hypertension associated with left ventricular diastolic dysfunction. Pulm Circ 2: 163-169.

4. Hassoun PM, Adnot S (2012) Update in pulmonary vascular diseases 2011 Am J Respir Crit Care Med 185: 1177-1182.

5. Papamatheakis DG, Kim NH (2015) Advances in the management of chronic thromboembolic pulmonary hypertension. Curr Hypertens Rep 17: 582.

6. Rose-Jones LJ, Mclaughlin VV (2015) Pulmonary hypertension: types and treatments. Curr Cardiol Rev 11: 73-79.

7. McLaughlin VV, McGoon MD (2006) Pulmonary arterial hypertension Circulation 114: 1417-1431.

8. Pandey A, Garg S, Khunger M, Garg S, Kumbhani DJ, et al. (2015) Efficacy and Safety of Exercise Training in Chronic Pulmonary Hypertension: A Systematic Review and Meta-Analysis. Circ Heart Fail.
*Corresponding author: Leonardo Roever, Department of Clinical Research, Av. Pará, 1720 - Bairro Umuarama.Uberlândia - MG - CEP 38400-902, Brazil, Tel: +553488039878; E-mail: leonardoroever@hotmail.com

Received October 15, 2015; Accepted October 31, 2015; Published November 07,2015

Citation: Roever L, Borges ASR (2015) Pulmonary Hypertension and Exercise Training: Evidence Based Studies. Lung Dis Treat 1: e103. doi:10.4172/24721018.1000e103

Copyright: @ 2015 Roever L, et al. This is an open-access article distributed unde the terms of the Creative Commons Attribution License, which permits unrestricted use, distribution, and reproduction in any medium, provided the original author and source are credited. 